\title{
Perspectives of Remote Sensing and GIS Applications in Tropical Forest Management
}

\author{
Mukete Beckline1, Sun Yujun 1, *, Baninla Yvette ${ }^{2}$ Achem Baye John ${ }^{3}$, Bakia Mor-Achankap ${ }^{4}$, \\ Sajjad Saeed ${ }^{1}$, Tamungang Richard ${ }^{4}$, Jaba Wose $^{4}$, Chalwe Paul ${ }^{5}$ \\ ${ }^{1}$ Department of Forest Management, Beijing Forestry University, Beijing, China \\ ${ }^{2}$ Research Center for Eco-Environmental Sciences, University of Chinese Academy of Sciences, Beijing, China \\ ${ }^{3}$ Faculty of Economic and Social Sciences and Solvay Business School, Vrije Universiteit Brussels, Belgium \\ ${ }^{4}$ Forest Monitoring and Evaluation Unit, Ministry of Forestry and Wildlife, Buea, Cameroon \\ ${ }^{5}$ Department of Forestry Economics and Management, Beijing Forestry University, Beijing, China

\section{Email address:} \\ munasawa@gmail.com (M. Beckline),sunyj@bjfu.edu.cn (S. Yujun),baninla2005@yahoo.com (B. Yvette), \\ jachembaye@yahoo.com (A. B. John),bmorachankap@yahoo.com (B. Mor-Achankap), sajjad_saeed222@yahoo.com (S. Saeed), \\ ttamungang@yahoo.com (T. Richard),jabawose@yahoo.com (J. Wose), chalwepaul@gmail.com (C. Paul) \\ ${ }^{*}$ Corresponding author
}

\section{To cite this article:}

Mukete Beckline, Sun Yujun, Baninla Yvette, Achem Baye John, Bakia Mor-Achankap, Sajjad Saeed, Tamungang Richard, Jaba Wose, Chalwe Paul. Perspectives of Remote Sensing and GIS Applications in Tropical Forest Management. American Journal of Agriculture and Forestry. Vol. 5, No. 3, 2017, pp. 33-39. doi: 10.11648/j.ajaf.20170503.11

Received: November 20, 2016; Accepted: December 13, 2016; Published: April 13, 2017

\begin{abstract}
Tropical forest management requires could be improved through the use of current technologies including remote sensing and Geographic Information System (GIS). In this paper, we characterize and evaluate forest management patterns and relate this to modern technologies such as geographical information systems and remote sensing. We further examine the application of these modern technologies in tropical forestry and conservation. To achieve this, we carried out a comprehensive survey of published scientific literature obtained through Web of Science, Mendeley, Researchgate and Google Scholar. We observed that, the relationships between forestry management, modern technologies have shifted over time. These have depended on how management activities such as planting and harvesting, interact with other drivers and disturbances (fire, pests and diseases) to influence the adaptive capacity of forests. Forest management and new technologies are interrelated because the technologies support management actions; hence contribute to global forest resources management and conservation.
\end{abstract}

Keywords: Forest Management, GIS, Remote Sensing, Tropical Forest Conservation, Forest Policy, Climate Change

\section{Introduction}

\subsection{Background}

Forests play an important role in regulating the global climate and serve as source of timber, fuel and fodder for forest dwellers (FAO, 2014; Bazezew et al., 2015). From complex ecosystems to monoculture plantations, forests are in high demand around a growing array of stakeholders including local communities, nations and multinational organizations (Duncker et al., 2012; CIFOR, 2015). Due to this high demand for forest resources, there is a necessity for forest management which takes the form of socioeconomic and social aspects of forestry.

Forest management involves the scientific and technical aspects of forestry including silviculture, protection, and regulation. These aspects are further classified into edaphic, sociopolitical, economic, demographic, biophysical, and market variables (Michon et al., 2007; MFR, 2008; Nasi et al., 2012). The management of forests varies in intensity from a leave alone, natural situation to a highly intensive regime with silvicultural interventions. With increasing public awareness of natural resource policies, forest management has shifted from a mere extraction of timber, to 
the conservation of biodiversity, forest resources, watershed management, recreation and carbon sequestration (Paivinen et al., 2010; Duncker et al., 2012). Many of these management actions also contribute to climate change mitigation through reducing emissions from forests, conserving forest carbon or enhancing forest carbon sinks (FAO, 2012). This awareness has also been facilitated by technological and scientific tools like remote sensing, TV, radio and GIS, all aimed at improving forest inventory and management (Mozgeris, 2009; Weber, 2012).

An emerging school of thought posits that forest resources and associated lands should be managed to meet the social, economic, ecological, cultural and spiritual needs of present and future generations. Therefore spatial data acquisition using GIS and remote sensing technology, and the assessment of forest resources are more than ever becoming necessary. These are creating the possibility to build spatial knowledge of biophysical and socioeconomic aspects of forest resources. Extensively used in mapping resources, land cover and land uses, it also allows the development of spatial models useful in predicting associated impacts. These characteristics facilitate in conceptualizing the situation and help in translating impacts prediction results into appropriate management plan and policy measures.

\subsection{Situational Analysis}

Globally, forests have suffered unprecedented destruction due to unsustainable exploitation and management of in-situ resources (Foahom, 2001; FAO, 2014). Poor management systems, combined with an intensification of forest use, have led to forest degradation and loss at a rate of about 13.5 million hectares per year (Foahom, 2001). For the people living near forests, these play a social, cultural and economic role. These multiple and sometimes competing interests in forest use, leads to controversies over environmental degradation, equity and persistent poverty. These controversies often translate into increased deforestation, unequal social access to resources and benefits, low land productivity, weak labour, and environmental policies (Karen, 2009; Celine et al., 2013).

\subsection{Relevance of the Study}

This study may be relevant to and assist policy makers and decision takers in fully exploiting the potentials of remote sensing and GIS technologies in forest management. This will specifically provide policy-making basis for the government while also contributing to forest conservation, through monitoring and evaluation activities. Benefits that could be derived from a full-scale exploitation of remote sensing and GIS technologies include the sustainable management of non-timber forest products. These non-timber forest products (NTFPs) could assist in providing forest dependent people with shelter, fuel, medicine and other services, while providing essential habitats for plants, animals, and safeguard against climate change (UNFCCC, 2015; WWF, 2015).

\subsection{Methodology}

To obtain a more up-to-date worldwide overview of modern technologies research on forestry, including those related to biodiversity and conservation, we conducted a general search of online scientific literature in Google Scholar and university catalogues. We used the keywords GIS, remote sensing, satellite imagery, forest management, forest conservation, silviculture, forest monitoring and evaluation. Scientific and other online media publications for over 25 years were selected for assessment. To make our search more comprehensive, we also examined other search engines such as Web of Science, Mendeley, and Researchgate databases and searched for similar documents.

The over 3000 publications obtained were then narrowed down to remote sensing and forestry. Here, we only examined documents relevant to our research on remote sensing, GIS, sustainable forest management, forest conservation, monitoring and evaluation. A bulk of these documents covered various other topics which were unrelated to any of our selected categories. For instance, we discarded publications involving research on socioeconomic issues, biodiversity and sustainability or which had empty links to remote sensing and GIS. Of the over 3000 publications, only about 152 publications had directly investigated modern technologies as related to forestry. These papers were mostly conducted in Europe, the Americas and Southeast Asia with very limited from Africa and the small Island states.

We then used this information to present a detailed analysis of management patterns of forest use and how these relate to geographical information systems and remote sensing technologies. In addition, we examine the relevance of these technologies in forest management and conservation. The paper is divided into two sections with the first looking at landuse and forest cover. Here, we explore the role of landuse changes on forest cover dynamics. In the second section, we look at the role of remote sensing and GIS technologies in studying these land uses and associated forest cover loss.

\section{Landuse and Forest Cover Change}

Landuse often results from the alteration of natural vegetation for different purposes such as logging, housing, agriculture and other forest related activities (Foley et al., 2005; Woodroffe and Sillero-Zubiri, 2012; Mukete et al., 2016). These changes result to a reduction in the availability of energy, water and nutrients to ecosystems and are far greater than ever in history (Geist and Lambin, 2002; Ellis, 2013; Mukete and Sun, 2014).

Indigenous peoples living at low population densities in tropical forests, practice sustainable shifting cultivation compatible with conservation. However, shifting cultivation at increasing population densities is a main driver of tropical forest cover changes (Brown, 2006; Anders, 2007). As many indigenous peoples in tropical forests currently experience 
rapid demographic growth, this raises the question to what extent their activities actually contribute to forest cover changes. Whereas these changes may seem negligible in terms of forest cover loss, they do cause hardships to the local people. This is due to increasing walking distance to old-growth forests, problems with weeds, pests and decreasing soil productivity when farming after re-clearing fallows (Anders, 2007; Asselen and Verburg, 2013).

Inventory and monitoring of landuse and landcover changes, are indispensable aspects for further understanding of change mechanisms. This is also important in modeling the impact of change on the environment and associated ecosystems at different scales. Thus, assessing the driving forces behind landuse is necessary, if past patterns are to be explained and used in forecasting future patterns (Turner et al., 1990; Diallo et al., 2009). These driving forces often include local culture (food preferences), economics (demand for specific products), environmental conditions (soil quality), land policy, and development programs (agricultural initiatives). Included in these driving forces are feedbacks between these factors such as past human activity on the land that existed in the form of maybe irrigation and roads (Oyekale et al., 2009; Ellis, 2013). Therefore, neither poverty nor population solely constitutes the major underlying cause of landcover changes (Lambin et al., 2001; Leemans et al., 2003). These landcover changes are rather related to human responses to economic opportunities as mediated by institutional factors and macroeconomic shocks. This is by creating opportunities and constraints for new land uses through local and national markets and policies. Hence, global forces are the primary cause of landuse and landcover changes, as they amplify or buffer local factors (Lambin et al., 2003, Geovana et al., 2015).

While landcover may be observed directly in the field or by remote sensing, observations of its changes generally require the integration of natural and social scientific methods. This aids in determining which human activities are occurring in different parts of the landscape, even when landcover appears to be the same (Angelsen and Kaimowitz, 2001, Lambin et al., 2003). Also, the distribution of natural landcover types is related to the heterogeneity of environmental conditions such as temperature and moisture. The actual distribution is however, only occasionally a result of physical limitations and it is mainly due to competition between individual plants or between ecosystems as a whole. This is also due to anthropogenic alteration of land which disrupts the structure and functioning of ecosystems. Agriculture, forestry, and other land-management practices have modified entire landscapes and altered plant and animal communities of many ecosystems throughout the world. The most spatially and economically important human uses of land globally include cultivation in various forms, livestock grazing, settlement and construction, reserves and protected lands, and timber extraction (Turner et al., 1994; Verburg, 2000).

\section{Remote Sensing, GIS and Tropical Forest Management}

Since 1972 when the first Landsat programme was launched, satellite data have been used in forest monitoring, evaluation and resources conservation. Satellite and remote sensing images combined with forest classification maps, aid in the efficient management of forest resources (Basuki et al., 2009). Studies by Angelsen and Kaimowitz, (2001) and Lambin et al., (2003) observed that Landsat data aids in determining which human activities are occurring in different parts of the landscape, even when landcover appears to be the same. Therefore scientific knowledge of landuse and landcover change is fundamental to improving our understanding of change mechanism. It is also necessary in modeling the impact of change on the environment and associated ecosystems. New and standardized continentspanning field networks are addressing many ecological issues, from forest succession to vegetation-atmosphere interactions (Saatchi et al., 2011; Mayes et al., 2015). New tools are also providing decision support for forest management, land resources utilization and ecological restoration (Pan et al., 2013).

According to Saatchi et al., (2011) and Mayes et al., (2015), assessing, monitoring and evaluating landcover changes, requires two most obvious variables for correlation (previous and actual size) and which can be determined by remote sensing, GIS and field work. For instance, using satellite, microwave observations of rainfall and canopy backscatter Saatchi et al., (2013), found that more than 70 million hectares (ha) of forest in western Amazonia experienced a strong water deficit during the dry season of 2005 and a closely corresponding decline in canopy structure and moisture. Remarkably and despite the gradual recovery in total rainfall in subsequent years, the decrease in canopy backscatter persisted until the next major drought, in 2010. Using Landsat data, Vitousek et al., (1997) noted that three of the well-documented global changes are increasing concentrations of carbon dioxide in the atmosphere, alterations in the biochemistry of the global nitrogen cycle, and on-going landuse and landcover change. The study observed that, globally humans have transformed significant portions of global land surface with $10-15 \%$ presently dominated by agriculture or urban-industrial areas and 6-8\%, by pasture. Additionally, Achard et al., (2002) using remote sensing data, observed a rate of decline of humid tropical forest of 4.9 million ha per year. In a separate study, Selçuk, (2008) found that landuse and landcover change (LULC) changes mostly occurred in Turkish coastal areas and in areas having low slope values.

Based on the analysis of remote sensing imagery and interviews with farmers Temudo and Silva, (2011) found that shifting cultivation in Africa is complex. They observed that change occurred in many directions and at different but simultaneous rates. Therefore, tropical deforestation is best explained by multiple causes and driving forces rather than by single-factor causation. Their study further revealed the 
advantage of combining remote sensing with ethnoagronomic data in the study of landuse and landcover changes. In another study using satellite images, JunJie and Li, (2013) showed that many socioeconomic phenomena such as urban sprawl; suburbanization, urban redevelopment, and economic segregation are closely related to forest cover changes. Similarly, Diallo et al., (2009) used remote sensing to highlight the importance of digital change detection in apprehending the environmental situation in the forested southern part of Yunnan Province, China. The study observed severe landcover changes to have occurred in croplands $(+24.90 \%)$, forest or shrub land $(-18.77 \%)$ and building $(+16.72 \%)$ areas. Thus the unused area constituted the most extensive type of landuse and landcover in the period under consideration. Using remote Landsat MSS and Spot XS, Meertens and Lambin (2000) observed that modeling land cover trajectories over several years, offered a better account of landcover change patterns than when just single observations are performed.

More research efforts have attempted to integrate remotesensing observations and field surveys at finer levels of aggregation such as at the scale of individuals, households or villages. Meli and Meli, 2015, used remotely sensed Landsat images to assess forest cover changes around the Santchou Wildlife Reserve of west Cameroon. The study observed that a combined regrowth of degraded lowland forest and abandoned farmlands is possible if factors that eliminated this secondary plant succession process are curtailed. Using a remote sensing approach with high resolution Rapid Eye satellite images, Willkomm et al., (2016) investigated general landuse and landcover structures and changes between 2010 and 2015 around Mt. Kenya region. The study observed that it is possible to detect main landcover classes and characterize the spatial and spectral mixture of different areas through remote sensing technology.

By comparing landcover disturbances as measured by remote sensing and landuse changes in Venezuela, Behrens et al., (1994) observed that they gained great insight into the processes leading to tropical deforestation and changes in landscape complexity. Similarly, Entwisle et al., (1998) attempted to link population dynamics as derived from field surveys to landuse and landcover change data in Thailand. Aggregated to the village-level, the household data offered an additional perspective to the remotely sensed landcover dynamics. The village profiles provided a crosscheck on the dynamics observed by remote sensing, and can be related to remotely sensed landscape variables (Entwisle et al., 1998).

Using a transdisciplinary framework that synthesized remote sensing and GIS analysis of landcover change, focus group dialogues and surveys, Pope et al., (2015) analyzed cloud forests in the Central Highlands of Guatemala. The study, found that expansion of subsistence agriculture is a key proximate cause of cloud forest removal, followed by extraction of fuelwood and larger-scale logging operations. Moran and Brondizio, (1998) investigated the linkages between remotely sensed data and traditional field methods in the social and biological sciences. The findings led them to new research issues including examination of the role of the developmental cycle of the household in shaping the landuse and deforestation trajectory. In Madgascar, Sussman et al., (1994) assessed how satellite imagery and ethnographic methods can contribute to an understanding of deforestation. The study highlighted the need for in-depth research on current patterns of landuse and existing resources to develop an integrated long-term conservation-oriented plan. In Nigeria, Guyer and Lambin (1993) combined household and remote sensing data to assess the level of intensification of farming systems. The study explored the relative role of two major drivers of landuse change which included population pressure and urban market expansion.

Globally, application of spatial data for forest resources management and planning has been recognized. Here, the spatial data will be less useful if they are not transformable into information, which can be systematically interpreted. Hence, there is a requirement to transfer and keep spatial data related to forestry in a standard computer format preferably in a GIS environment (Hamzah, 2001). A GIS is an integrated resource data base system that has the capability to store, edit and process digital data; and that supports development planning and policy analysis.

According to Dahdou-Guebas (2005a), the use of GIS in socioeconomic studies especially in human geography has become very important. Relatedly, Hamzah (2001), also observed that GIS has gained a lot of credence in forest resources management. Hence, alongside remote sensing, GIS has turned into an indispensable scientific technology for local, regional as well as global landuse and landcover change studies (Saatchi et al., 2011; Mayes et al., 2015). Within the past decades, GIS has often been used in combination with remote sensing especially in studies on ecological models, agricultural intensification, pests and diseases, forest fires and droughts monitoring as well as wetlands and forest conservation (Saatchi et al., 2013). As the size and physical terrain of forests make it difficult to survey, global positioning system (GPS) makes it easier, faster and more accurate to create land surveys. Globally, GIS is primordial in tropical forestry research, data analysis and presentation especially for cross-cutting subject areas (Turner et al., 2001). Thus, it is useful in the provision and continuous monitoring of forest evolution because of its capacity to detect changes and incorporate the results into an available database for reference and future use purposes.

\section{Conclusion}

In this study, we have analyzed forest management patterns and explored the necessity for incorporating geographical information systems and remote sensing technologies in tropical forest resources management and conservation. GIS and remote sensing support management actions and by so doing contribute to global forest resources management and conservation. Appropriate forests resources monitoring, evaluation and management can only be achieved when an excellent information system and database 
are put in place or established by a country. Therefore, the effective application of remote sensing and GIS technology in tropical forestry will go a long way to accurately assess and analyze landuse changes. It will also identify areas of deforestation, forest conversion, and degradation while identifying its direct and indirect causes (primary mechanisms and driving factors behind forest change). GIS and remote sensing applications are not only financially engaging to poor countries, they are also still under-exploited in landuse, landcover change, forest resources, and natural resources management.

\section{Acknowledgement}

This study is part of a research project funded by the World Wildlife Fund and the Russel Train Environment for Nature (WWF/EFN) Grant No. ST60. The authors are also grateful to Justice Mukete Tahle, Lonje Bernard, Motia Henry, the Chinese Scholarship Council and the Cameroon Ministry of Forestry and Wildlife, Buea for their assistance.

\section{References}

[1] Achard, F., Eva, H. D., Hans-Jürgen, S., Mayaux, P., Gallego, J., Richards, T and Malingreau, J (2002). Determination of Deforestation Rates of the World's Humid Tropical Forests. Science 297: 999-1002.

[2] Anders, H (2007). Population Growth and Land Use Intensification in a Subsistence-based Indigenous Community in the Amazon. Human Ecology 35 (6): 669-680.

[3] Angelsen, A and Kaimowitz, D (2001). Agricultural Technologies and Tropical Deforestation. Wallingford, UK: CABI Publishing. 440 pp. ISBN: 0851994512.

[4] Asselen, V and Verburg, H (2013). Land cover change or land-use intensification: simulating land system change with a global-scale land change model. Global Change Biology 19 (12): 3648-3667.

[5] Basuki, M., Van-Laake, E., Skidmore, A and Hussin, Y (2009). Allometric equations for estimating the above-ground biomass in tropical lowland Dipterocarp forests. Forest Ecology and Management, 257 (8): 1684-1694.

[6] Behrens, C., Baksh, M and Mothes, M (1994). A regional analysis of Bari land use intensification and its impact on landscape heterogeneity. Human Ecology 22 (3): 279-316.

[7] Brown, D (2006). Personal Preferences and Intensification of Land Use: Their Impact on Southern Cameroonian Slash-andBurn Agroforestry System. Agroforestry Systems 68: 53-67.

[8] Celine, E., Mayaux, P., Verhegghen, A., Bodart, C., Musampa, C and Defourny, P (2013). National forest cover change in Congo basin: Deforestation, reforestation, degradation and regeneration for the years 1990, 2000 and 2005. Global Change Biology 19: 1173-1187.

[9] CIFOR (2015). Center for International Forestry Research. Forest Management. Available at: http://www.cifor.org/forestmanagement $/$. Accessed $4^{\text {th }}$ November, 2015.

[10] Dahdouh-Guebas F., Van Hiel, E., Chan, W., Jayatissa, L and
Koedam, N (2005a). Qualitative distinction of congeneric and introgressive mangrove species in mixed patchy forest assemblages using high spatial resolution remotely sensed imagery (IKONOS). Systematics and Biodiversity 2 (2): 113119.

[11] Diallo, Y., Guangdao, H and Xingping, W (2009). Applications of Remote Sensing in LULC Change Detection in Puer and Simao Counties. Marsland Press Journal of American Science 5 (4): 157-166.

[12] Duncker, S., Barreiro, M., Hengeveld, T., Lind, W., Mason, L., Ambrozy, S and Spiecker, H (2012). Classification of forest management approaches: a new conceptual framework and its applicability to European forestry. Ecology and Society 17 (4): 51 .

[13] Ellis, E (2013). Land-use and land-cover change. Retrieved from www.eoearth.org/view/article/154143.

[14] Entwisle, B., Walsh, J., Rindfuss, R and Chamratrithirong, A (1998). Land-use/land-cover and population dynamics, Nang Rong, Thailand. In D. Liverman, E. F. Moran, R. R. Rindfuss, \& P. C. Stern, People and pixels: linking remote sensing and social science (pp 121-144). Washington, DC: National Academy Press.

[15] FAO (2012). Food and Agriculture Organization of the United Nations. Forest management and climate change: a literature review. Forests and Climate change Working Paper No. 10 Rome, Italy. Available at: http://www.fao.org/docrep/015/md012e/md012e00.pdf. Accessed: $11^{\text {th }}$ October, 2015.

[16] FAO (2014). Global Forest Resources Assessment and the State of the World's Forests. Rome, Italy.

[17] Foahom, B (2001). Biodiversity Planning Support Programme Integrating Biodiversity into the Forestry Sector. Cameroon Case Study. Paper prepared for an international workshop on "Integration of Biodiversity in National Forestry Planning Programme" Bogor, Indonesia on $13^{\text {th }}-16^{\text {th }}$ August 2001. Available at: https://www.cbd.int/doc/nbsap/forestry/cameroon.pdf.

[18] Foley, J., Defries, R., Asner, G., Bardford, C., Bonan, G., Carpenter, R., Chapin, F., Coe,T., Daily, C., Gibbs,K., Helkowski, J., Holloway, T., Howard, E, Kucharik, J., Monfreda, C., Patz, A., Prentice, I., Ramankutty, N and Snyder, P (2005). Global consequences of land use. Science 309: $570-574$

[19] Geist, H and Lambin, E (2002). Proximate causes and underlying driving forces of tropical deforestation. BioScience, 52 (2): 143-50.

[20] Geovana, C., Marielos, P., Bongers, F., Díaz, S., Quétier, F., Chuviña, J and Poorter, L (2015). In press. Land-use intensification effects on functional properties in tropical plant communities. Ecological Applications. http://dx.doi.org/10.1890/14-0340.1.

[21] Guyer, J and Lambin, E (1993). Land use in an urban hinterland: Ethnography and remote sensing in the study of African intensi ${ }^{\circledR}$ cation. American Anthropologist 95 (4), $839 \pm 859$

[22] Hamzah, A (2001). Remote Sensing, GIS and GPS as a Tool to Support Precision Forestry Practices in Malaysia. Available at http://www.crisp.nus.edu.sg/ acrs2001/pdf/276HAMZA.PDF. 
[23] JunJie, W and Li, M (2013). A Background Paper Submitted to the International Food Policy Research Institute under Agreement \# 200002.000.180 515-01-01 Final Report, November 2013.

[24] Karen, M (2009). Demographics, Democracy, Development, Disparity and Deforestation: A Cross-national Assessment of the Social Causes of Deforestation. Retrieved 13th May, 2015.

[25] Lambin, E., Turner, B., Geist, H., Agbola, S and Angelsen, A (2001). The causes of land-use and land-cover change: moving beyond the myths. Global Environmental Change, 11 (4): 261-69.

[26] Lambin, E., Geist, H and Lepers, E (2003). Dynamics of land use and cover change in tropical regions. Annual Rev. Environ. Resources 28: 205-241.

[27] Leemans, R., Lambin, E., McCalla A., Nelson, J., Pingali, P and Watson, B (2003). Drivers of change in ecosystems and their services. In Ecosystems and Human Well-Being: A Framework for Assessment, ed. H. Mooney, A. Cropper, W. Reid. Washington, DC: Island Press. ISBN: 1559634030.

[28] Mayes, T., Mustard, F and Melillo, J (2015). Forest cover change in Miombo Woodlands: Modeling land cover of African dry tropical forests with linear spectral mixture analysis. Remote Sensing of Environment 165: 203-215.

[29] Meli, F and Meli, V (2015). Modelling Drivers of Forest Cover Change in the Santchou Wildlife Reserve, West Cameroon using Remote Sensing and Land Use Dynamic Degree Indexes. Canadian Journal of Tropical Geography 2 (2): $29-42$.

[30] Mertens, B and Lambin, E (2000). Land Cover change trajectories in the South of Cameroon. Annuals of the Association of American Geographers 90 (3) 467-494.

[31] Michon, G., De Foresta, H., Levang, P and Verdeaux, F (2007). Domestic forests: a new paradigm for integrating local communities' forestry into tropical forest science. Ecology and Society 12 (2): 1 . Available at: http://www.ecologyandsociety.org/vol12/iss2/art1/. Accessed $11^{\text {th }}$ October, 2015.

[32] MFR (2008). Ministry of Forests and Range, Canada. Glossary of Forestry Terms in British Columbia. Available at: http://www.for.gov.bc.ca/hfd/library/documents/glossary/Glos sary.pdf. Accessed $18^{\text {th }}$ November, 2015.

[33] Moran, E and Brondizio, E (1998). Land-Use Change After Deforestation in Amazonia, In People and Pixels: Linking Remote Sensing and Social Science (D. Livermann, E. F. Moran, R. R. Rindfuss and P. C. Stern, editors), National Academy Press, Washington D. C., pp. 94-120.

[34] Mozgeris, G (2009). The continuous field view of representing forest geographically: from cartographic representation towards improved management planning. S. A. P. I. EN. S 2.2 2009. Available at:

http://sapiens.revues.org/734. Accessed $18^{\text {th }}$ November 2015.

[35] Mukete, B and Sun, Y (2014). Assessing the Effectiveness of Urban Nature Reserves on Biodiversity Conservation. Applied Ecology and Environmental Sciences 2 (6) 130-134.

[36] Mukete, B., Sun, Y., Zama, E and Monono, S (2016). Paper Consumption and Environmental Impact in an Emerging Economy. Journal of Energy, Environmental \& Chemical Engineering. (1) 1:13-18.
[37] Nasi, R., Billand, A and Vanvliet, N (2012) Managing for timber and biodiversity in the Amazon Basin. For. Ecol. Management 268: 103-111.

[38] Oyekale, S., Bolaji, M and Olowa, W (2009). The effects of climate change on cocoa production and vulnerability assessment in Nigeria. Agricultural Journal 4 (2): 77-85.

[39] Pan, Y., Birdsey, R., Phillips, L and Jackson, R (1999). The Structure, Distribution, and Biomass of the World's Forests. Annual Review of Ecology, Evolution, and Systematics 44: 593-622.

[40] Paivinen, R., Lindner, M., Rosen, K and Lexer, J (2010). A concept for assessing sustainability impact of forestry wood chains. European Journal of Forest Research. Available at: http://dx.doi.org/10.1007/s10342-010-0446-4. Accessed 11 ${ }^{\text {th }}$ September, 2015.

[41] Pope, I., Bowenc, D., Harbora, J., Shaod, G., Zanottie, L and Burniske, G (2015). Deforestation of montane cloud forest in the Central Highlands of Guatemala: contributing factors and implications for sustainability in Q'eqchi' communities. International Journal of Sustainable Development and World Ecology 22 (3): 201-212.

[42] Saatchi, S., Harris, L., Brown, S., Lefsky, M., Mitchard, A., Salas, W., Zutta, R., Buermann, W., Lewis, L., Hagen, S., Petrova, S., White, L., Silman, M and Morel, A (2011). Benchmark map of forest carbon stock in tropical regions across three continents. Proceeding of the National Academy of Sciences of the United States of America 108 (24): 98999904.

[43] Saatchi, S., Asefi-Najafabady, S., Malhi, Y., Aragão, C., Anderson, O., Mynenif, R and Nemanig, R (2013). Persistent effects of a severe drought on Amazonian forest canopy. Proceeding of the National Academy of Sciences of the United States of America 110 (2): 565-570.

[44] Selçuk, R (2008). Analyzing Land Use/Land Cover Changes Using Remote Sensing and GIS in Rize, North-East Turkey. Sensors 8: 6188-6202.

[45] Sussman, R., Green, G and Sussman, L (1994). Satellite imagery, human ecology, anthropology and deforestation in Madagascar. Human Ecology, 22 (3): 333 \pm 354.

[46] Temudo, M and Silva, J (2011). Agriculture and forest cover changes in post-war Mozambique. Journal of Land Use Science 7 (4): 425-442.

[47] Turner, L., Moss, R and Skole, D (1994). Relating land-use and global land-cover change: a proposal for an IGBP-HDP core project. International Geosphere Biosphere Project, IGBP Report No. 4, IGBP, Stockholm. Available at: http://www.ciesin.org/docs/002-105/002-105.html Accessed $12^{\text {th }}$ January, 2015.

[48] Turner, B., Clark, C., Kates, W., Richards, J., Mathews, T and Meyer, B (1990). The Earth as Transformed by Human Action: Global and Regional Changes in the Biosphere over the Past 300 Years. Cambridge University Press with Clark University, Cambridge; New York.

[49] UNFCCC (2015). United Nations Framework Convention on Climate Change. Report of the conference of the parties on its twentieth session, held in Lima, Peru $1^{\text {st }}-14^{\text {th }}$ December 2014. Available at: http://unfccc.int/resource/docs/2014/cop20/eng/10a02.pdf. Accessed $14^{\text {th }}$ November, 2015. 
[50] Vitousek, P., Aber, J., Howarth, R., Likens, G., Matson, P., Schindler, D., Schlesinger, W and Tilman, G (1997). Human alteration of the global nitrogen cycle: sources and consequences. Ecological Applications 7: 737-750.

[51] Weber, N (2012). Reflections on theories in forest policy: Testing, combining or building? Forest Policy and Economics 16: $102-108$.

[52] Willkomm, M., Vierneisel, B and Dannenberg, P (2016). Land use change dynamics in the Mt. Kenya region - a remotely sensed analysis using RapidEye satellite images. Zbl. Geol. Paläont. Teil I, 1: 23-40.

[53] Woodroffe, R and Sillero-Zubiri, C (2012). Lycaon pictus. The IUCN Red List of Threatened Species 2012:e.T12436A16711116.http://dx.doi.org/10.2305/IUCN.U K.2012.RLTS.T12436A16711116.en. Downloaded on 21 September 2015. 